\title{
JONG KINDERS SE GEBRUIK VAN KOMMUNIKASIEFUNKSIES VóóR EN Ná KOGLEêRE INPLANTING
}

\author{
Inge Kaltenbrünn, Brenda Louw en René Hugo
}

Departement Kommunikasiepatologie

Universiteit van Pretoria

\section{OPSOMMING}

Hierdie artikel beskryf vyf jong kinders met kogleêre inplantings se gebruik van kommunikasiefunksies, in 'n poging om die invloed van die kinders se vroeë intensionele kommunikasiegedrag op hulle individuele kommunikasievaardighede ná kogleêre inplanting te ondersoek. Video-opnames van elk van die vyf deelnemers in ongestruktureerde vryespelinteraksie met hulle versorgers, vóor kogleêre inplanting en twaalf en agtien maande ná kogleêre inplanting, is gebruik om die aard en die voorkoms van hulle kommunikasiefunksies oor tyd te identifiseer. Die Communicative Intention Inventory (Coggins \& Carpenter, 1981) is gebruik om die kommunikatiewe gedrag van die deelnemers te klassifiseer volgens die soorte kommunikasiefunksies wat gebruik is. Resultate van die ondersoek toon dat die aard en die voorkoms van die kommunikasiefunksies merkbaar vóór en ná kogleêre inplanting verskil het en die deelnemers se toenemende bevoegdheid om aan gespreksinteraksie deel te neem, gedemonstreer het. Individuele verskille tussen die deelnemers in hulle gebruik van heuristiese en informatiewe kommunikasiefunksies het moontlik 'n verklaring gebied vir die voorkoms van interkliëntvariasie in die tempo van verbale kommunikasie-ontwikkeling ná kogleêre inplanting. Die resultate word as betekenisvol beskou in die kliniese besluitnemingsproses met betrekking tot die kogleêre-inplantingkandidaatskap van jong kinders onder die ouderdom van drie jaar met 'n ernstige gehoorverlies en hulle terapeutiese hantering. Die resultate dra ook by tot die identifisering van 'n objektiewe vroeë kommunikasieevalueringsprotokol vir jong kinders met 'n ernstige gehoorverlies in 'n prelinguistiese stadium van taalontwikkeling.

Sleutelwoorde: Intensionaliteit, Kommunikasiefunksies, Preverbale kommunikasie, Ernstige gehoorverlies, Kogleêre inplanting.

\section{ABSTRACT}

This paper describes the communication functions of five young children with cochlear implants in order to study the influence of these children's early intentional communication on their individual communication skills after cochlear implantation. Video recordings of each of the five participants in unstructured free play interaction with their,caregivers, before cochlear implantation and twelve and eighteen months after cochlear implantation, were used to identify the type and occurrence of their communication functions over time. The Communicative Intention Inventory (Coggins \& Carpenter, 1981) was used to classify the communicative behaviour of the participants according to the types of communication functions that were used. Results of the study show that the type and occurrence of the communication functions differed before and after cochlear implantation and demonstrated the participants' increased ability to participate in conversation. Individual differences amongst the participants in their use of informative and heuristic communication functions could possibly account for interclient variability in the rate of verbal communication development after cochlear implantation. The results are seen as meaningful in clinical decision-making regarding the suitability of young children under the age of three with a profound hearing loss for cochlear implantation and their therapeutic management. The results also contribute to the identification of an objective protocol for the evaluation of the early communication of young children with a profound hearing loss who are in a prelinguistic stage of language development.

Key Words: Intentionality, Communication functions, Preverbal communication, Profound hearing loss, Cochlear implant.

\section{INLEDDING}

Kogleêre inplantings is een van die opwindendste tegnologiese ontwikkelinge op die gebied van oudiologie. Geen ander sensoriese hulpmiddel het tot dusver so 'n dramatiese impak gehad op die bevordering van verbale kommunikasieontwikkeling by kinders met 'n ernstige gehoorverlies nie (Houston, Ying, Pisoni \& Kirk, 2003).

Kogleêre inplantingseenhede wêreldwyd verskaf deesdae toenemend kogleêre inplantings aan jong, ernstig gehoorgestremde kinders onder die ouderdom van drie jaar (Wright, Purcell \& Reed, 2002). Navorsingsbevindinge wys daarop dat kinders wat onder die ouderdom van 36 maande kogleêre inplantings ontvang, beter spraakpersepsie en spraaken taaluitkomste toon as kinders wat kogleêre inplantings ontvang tussen die ouderdomme van 37 en 60 maande (Zwolan,
2000). Die verskaffing van kogleêre inplantings aan kinders jonger as 36 maande bied die geleentheid om deur vroeë intervensie die verloop van hulle verbale kommunikasie-ontwikkeling positief te beïnvloed (McConkey Robbins, 2003). Ook in SuidAfrika ontvang al meer jong kinders tussen die ouderdomme van 12 en 36 maande kogleêre inplantings (Müller, persoonlike onderhoud, 16 April 2003). Deur kogleêre inplantings aan jong kinders te verskaf, poog die vier kogleêre-inplantingseenhede in Suid-Afrika (twee in Gauteng, een in die Vrystaat en een in die Wes-Kaap) om dus deur vroeë intervensie die impak van die gehoorverlies op dié kinders se spraak- en taalontwikkeling te beperk.

Suid-Afrika is egter ' $n$ land met beperkte finansiële hulpbronne in die openbare sektor. Die haalbaarheid van kogleêre inplantings in 'n land soos Suid-Afrika word gevolglik dikwels bevraagteken op grond van die hoë kostes daaraan verbonde 
(Penn, 1993). Ten einde die finansiële haalbaarheid van kogleêre inplantings in Suid-Afrika te regverdig, moet die effektiwiteit van kogleêre inplantings by jong kinders ondersoek word en objektiewe kliniese en wetenskaplike bewyse verskaf word van hoe jong kinders by kogleêre inplantings baat (Sanderson \& Nash, 2002). Die belang hiervan in die Suid-Afrikaanse konteks word veral duidelik indien in ag geneem word dat vroeë intervensie kostebesparend is (Rossetti, 2001). Vir elke VSA Dollar wat op vroeë intervensie spandeer word, word $\$ 6$ op latere gespesialiseerde onderwys gespaar (Rossetti, 2001).

Die invloed van vroeë intervensie deur kogleêre inplantings lewer egter tans 'n verskeidenheid van gevolge. Individuele verskille in prestasie op spraakpersepsietoetse, op gestandaardiseerde spraak- en taalevalueringsprosedures en op beskrywende resultate van die evalueringsmetodes kom voor onder jong kinders met kogleêre inplantings (Houston, Ying, Pisoni \& Kirk, 2003). Tot dusver kon hierdie individuele verskille in jong kinders se spraakpersepsie- en verbale kommunikasie-uitkomste met 'n kogleêre inplanting nie deur navorsing verklaar word nie (Kirk, 2000).

Navorsing oor individuele verskille en variasie in prestasie bied dus 'n uitdaging vir spraak-taalterapeute en/of oudioloë en navorsers werksaam op die gebied van kogleêre inplantings (McConkey Robbins, Green \& Bollard, 2000). Hierdie kwessie is gevolglik een van die belangrikste rigtings wat navorsing tans in die gebied inslaan (Pisoni, 2000).

Verskeie demografiese veranderlikes is wel bevind om 'n rol te speel om standaarduitkomsmetings op spraakpersepsie- en taalevalueringsprosedures by kinders met kogleêre inplantings te voorspel, en individuele verskille ten opsigte van vordering met kogleêre inplantings te verklaar, byvoorbeeld die ouderdom tydens die aanvang van die gehoorverlies, die duur van die gehoorverlies, die ouderdom tydens die ontvangs van die kogleêre inplanting en die keuse van 'n uitsluitlik verbale wyse van kommunikasie (Osberger, Todd, Berry, Robbins \& Miyamoto, 1991).

Jong kinders se vordering ten opsigte van verbale kommunikasie-ontwikkeling ná kogleêre inplanting mag egter ook moontlik die resultaat wees van ouditief-perseptuele leer wat eerder verband hou met veranderinge in neurale ontwikkeling weens maturasie, asook blootstelling an die geselekteerde taal in die omgewing en spesifieke eienskappe van die taalleeromgewing (Pisoni, Cleary, Geers \& Tobey, 2000). Die bestudering van demografiese veranderlikes verskaf egter nie inligting oor die wyse waarop kinders met kogleêre inplantings hierdie onderliggende neurale en perseptuele prosesse en kognitiewe en linguistiese vaardighede toepas op die elektriese sein wat deur die kogleêre inplanting verskaf word, ten einde verbale taal aan te leer nie (Pisoni, 2000). Tradisionele uitkomsmetings behoort gevolglik vervang te word deur metings van die prosesse onderliggend aan verbale kommunikasie-ontwikkeling, in 'n poging om die voorkoms van interkliëntvariasie in die pediatriese populasie se sukses met kogleêre inplantings te verklaar (Pisoni et al., 2000).

Die vraag kan egter gestel word: Hoe kan metings van die prosesșe onderliggend aan jong kinders met kogleêre inplantings se verbale kommunikasie-ontwikkeling gemaak word in die lig daarvan dat hierdie kinders meestal op 'n preverbale stadium van taalontwikkeling funksioneer, weens hulle ouderdom en die gevolge van die graad van hulle gehoorverlies? (Dyar, 2003).

Pisoni et al. (2000) beantwoord hierdie vraag deur daarop te wys dat jong kinders met kogleêre inplantings se preverbale kommunikasiegedrag moontlik onderliggende multimodale in- teraksies tussen persepsie en aksies weerspieël wat nie met 'n spesifieke sensoriese modaliteit verband hou nie, aangesien preverbale kommunikasiehandelinge as die basis beskou word waaruit alle kinders verbale taal ontwikkel. Deur dus jong kinders met kogleêre inplantings se onderliggende preverbale kommunikasiehandelinge te bestudeer kan die onderlinge verskille in die kinders se verbale kommunikasie-uitkomste verklaar word en hulle potensiaal vir verbale kommunikasie-ontwikkeling voorspel word (Tait, Lutman \& Robinson, 2000).

Navorsing oor die ontwikkeling van preverbale intensionele kommunikasievaardighede by jong kinders met kogleêre inplantings het tot dusver hoofsaaklik gefokus op die wyse waarop die kinders vóór en ná kogleêre inplanting aan vroeẻ kommunikasiehandelinge uitdrukking gegee het, bv. vokaal, by wyse van informele gebare of verbaal (Tait et al., 2000). Die ontwikkeling van intensionele kommunikasie behels egter nie slegs ' $n$ verandering in die wyse waarop die jong kind aan kommunikasiehandelinge uitdrukking gee nie, maar intensionele gedrag reflekteer ook die omvang van die verskillende kommunikasiefunksies waaraan 'n kind op 'n spesifieke stadium van kommunikasie-ontwikkeling uitdrukking gee (Wetherby \& Prizant, 1989). Navorsing gerig op die ontwikkeling van preverbale kommunikasievaardighede by jong kinders met kogleêre inplantings behoort dus die ontwikkeling van intensionele kommunikasie by hierdie kinders as 'n tweedimensionele ontwikkelingsproses in ag te neem deur beide die ontwikkeling van die kommunikasiewyse en die ontwikkeling van kommunikasiefunksies te ondersoek.

Sover bekend het slegs twee navorsingsprojekte, naamlik een deur Nicholas (1994) en 'n ander deur Wright, Purcell en Reed (2002), die aard en die voorkoms van die kommunikasiefunksies wat spesifiek deur jong kinders met kogleêre inplantings oor tyd gebruik is, ondersoek. Nicholas (1994) se navorsing het hoofsaaklik op kinders met 'n ernstige gehoorverlies se ontwikkeling van kommunikasiefunksies ná kogleêre inplanting gefokus. Die preverbale kommunikasievaardighede wat kinders met 'n ernstige gehoorverlies vóór kogleêre inplanting gebruik, kan egter hulle kommunikasie-uitkomste ná kogleêre inplanting beïnvloed (Tait, Lutman \& Robinson, 2000). Tait et al. (2000) het aangedui dat tot 'n kwart van die variansie in 'n groep jong kinders met kogleêre inplantings se prestasie op spraakidentifiseringstake drie jaar ná kogleêre inplanting voorspel kon word deur die onderliggende preverbale gedrag wat die kinders vóór kogleêre inplanting geopenbaar het en spesifiek deur hulle gebruik van vokale- of gebare-outonomie. Gevolglik behoort ook jong ernstig gehoorgestremde kinders se gebruik van kommunikasiefunksies vóór kogleêre inplanting deur navorsing ondersoek te word.

Wright, Purcell en Reed (2002) het bevind dat jong kinders vóór kogleêre inplanting 'n verskeidenheid nieverbale kommunikasiefunksies gebruik het, maar dat beduidende individuele verskille twaalf maande ná kogleêre inplanting in die kinders se verbale kommunikasie voorgekom het. Hierdie navorsingsresultate beklemtoon die behoefte daaraan om intensionele kommunikasiefunksies vóór en ná kogleêre inplanting te identifiseer wat kinders se individuele kommunikasie-uitkomste met 'n kogleêre inplanting kan beïnvloed. Die verhouding tussen die aard en die voorkoms van die kommunikasiefunksies wat jong kinders met 'n ernstige gehoorverlies vóór en ná kogleêre inplanting gebruik en hulle individuele kommunikasiebevoegdheid ná kogleêre inplanting is egter nog nie deur navorsing ondersoek nie.

Gevolglik ondersoek die huidige navorsing die aard en 
die voorkoms van die kommunikasiefunksies wat jong kinders met 'n ernstige gehoorverlies vóór en ná kogleêre inplanting gebruik, asook die invloed van dié kinders se gebruik van kommunikasiefunksies op hulle individuele kommunikasiebevoegdheid ná kogleêre inplanting.

\section{METODIEK}

\section{Doelstelling}

Om die aard en die voorkoms van die kommunikasiefunksies wat oor tyd deur die proefpersone gebruik is, te beskryf deur die kommunikasiefunksies wat op spesifieke tydsintervalle voorkom, te identifiseer.

\section{Navorsingsontwerp}

Die navorsingsontwerp het 'n longitudinale, retrospektiewe, beskrywende opname deur middel van enkelgevalstudies behels. As gevolg van die mate waartoe individuele verskille onder jong kinders met kogleêre inplantings ten opsigte van hulle intensionele kommunikasie-ontwikkeling voorkom, kan hulle vroeë kommunikasie-ontwikkeling ten beste gekwantifiseer word deur uitkomsdata vir elke individuele kind binne 'n enkelgeval-navorsingsontwerp te versamel (Leedy \& Ormrod, 2001; Tyler, 1993).

Die verkreë data is deur middel van beskrywende statistiek hanteer. Kwalitatiewe besprekings van die resultate is aanvullend tot die kwantitatiewe verwerking van die resultate uitgevoer, omdat hierdie ' $n$ beskrywende opname is (Leedy \& Ormrod, 2001).

\section{Deelnemers}

Die proefpersone wat aan hierdie navorsing deelgeneem het, was jong kinders met kogleêre inplantings.

\section{Beskrywing van die proefpersone}

Vyf kinders met ' $n$ ernstige kongenitale gehoorverlies het aan die seleksiekriteria voldoen en is geselekteer om aan die navorsing deel te neem. Die proefpersone het tussen die ouderdomme van 2 jaar en 3 jaar 2 maande 'n multikanaalkogleêre inplanting ontvang. Die gemiddelde kronologiese ouderdom waarop die proefpersone die kogleêre inplanting ontvang het, was 2 jaar 8 maande. Proefpersone 1 en 3 het van 'n Cochlear Nucleus 24 multikanaal- kogleêre inplanting gebruik gemaak, terwyl proefpersone 2, 4 en 5 'n Cochlear Nucleus 22 multikanaal- kogleêre inplanting gebruik het.

Al die proefpersone het vir die duur van die navorsing van die SPEAK koderingstrategie gebruik gemaak. Al die proefpersone was in die Carel du Toit Sentrum vir Gehoorgestremde Kinders, Kaapstad, se ouditief-orale ouerleidingsprogram geplaas.

\section{Etiese aspekte}

Ten einde aan etiese standaarde van navorsing te voldoen is goedkeuring van die etiese prosedures in die huidige navorsing van die Navorsingsvoorstel- en Etiekkomitee, Fakulteit Geesteswetenskappe, Universiteit van Pretoria verkry. Die versorgers van die proefpersone is ook versoek om 'n brief van ingeligte toestemming te onderteken om hulle en hulle kind se vrywillige deelname aan die navorsing te bevestig. Die proefpersone en hulle versorgers is deurgaans verseker van die vertroulikheid van die resultate en dat hulle identiteit anoniem gehou sal word.

\section{Apparaat en Materiaal}

Die navorsingsapparaat en materiaal wat in die datainsameling gebruik is, word in Tabel 1 uiteengesit.

Tabel 1 Apparaat en materiaal

\begin{tabular}{|c|c|c|}
\hline Afdeling & Klassifikasie & Doel van gebruik \\
\hline Opnamé-apparaat & $\begin{array}{l}\text { - Videotoerusting: } \\
\text { - Panasonic NV-RX11VHS-C draagbare } \\
\text { videokamera } \\
\text { Vidéobande: Hoë kwaliteit Panasonic NV- } \\
\text { EC } 45 \text { XPA Compact videobande }\end{array}$ & $\begin{array}{l}\text { Vaslegging van versorger-kindinteraksie oudio-visueel (Cole \& St. } \\
\text { Clair-Stokes, 1984; Tait, 1993) }\end{array}$ \\
\hline $\begin{array}{l}\text { Opname- } \\
\text { ontledingsapparaat }\end{array}$ & $\begin{array}{l}\text { - Philips televisieskerm } \\
\text { - } \quad \text { AIM VHS videomasjien }\end{array}$ & $\begin{array}{l}\text { Oudio-visuele voorstelling van versorger-kindinteraksie soos vasgelê op } \\
\text { videoband. }\end{array}$ \\
\hline Merklys & $\begin{array}{l}\text { Infant-Toddler Meaningful Auditory Integration } \\
\text { Scale (IT-MAIS) (Robbins, Renshaw \& Berry, } \\
\text { 1991) }\end{array}$ & $\begin{array}{l}\text { Bepaling van die proefpersone se kogleêre inplantinggebruikstatus } \\
\text { (Osberger, 1995). }\end{array}$ \\
\hline Waarnemingsvorm & $\begin{array}{l}\text { Communicative Intention Inventory (Coggins \& } \\
\text { Carpenter, 1981) }\end{array}$ & $\begin{array}{l}\text { Kodering van kommunikasiefunksies tydens analise van video-opnames } \\
\text { van versorger-kindinteraksie in 'n sosiale konteks (Yoshinaga-Itano \& } \\
\text { Stredler-Brown, 1992). }\end{array}$ \\
\hline $\begin{array}{l}\text { Materiaal tydens } \\
\text { vryespelsessies }\end{array}$ & $\begin{array}{l}\text { Vasgestelde ouderdomstoepaslike spelakti- } \\
\text { witeite soos voorgestel deur Tait (1993): } \\
\text { - Waterspel } \\
\text { - Bad van 'n pop } \\
\text { - Spel met teegerei } \\
\text { - Pophuisspeelgoed }\end{array}$ & $\begin{array}{l}\text { Manipulerende en tematiesverwante speelgoed sal dit moontlik maak } \\
\text { om die kommunikasiefunksies, versoeke en kommentaarlewering, ook in } \\
\text { ongestruktureerde vryespelsessies te ontlok (Wetherby \& Rodriguez, } \\
\text { 1992). Spelaktiwiteite skep 'n sosiale konteks waarbinne die tipiese } \\
\text { kommunikatiewe gedrag van beide die versorger en die kind na vore kan } \\
\text { tree (Yoshinaga-Itano \& Stredler-Brown, 1992). }\end{array}$ \\
\hline
\end{tabular}




\section{PROSEDURES}

\section{Data-insamelingsprosedures}

Die data is deur video-opnames van die vyf proefpersone in interaksie met hulle versorgers ingesamel (Coggins \& Carpenter, 1981). Die video-opnames vir elke proefpersoon is vóór kogleêre inplanting en twaalf en agtien maande ná kogleêre inplanting gemaak. Die video-opnames het bestaan uit ongestruktureerde vryespelsessies tussen die proefpersone en hulle onderskeie versorgers. Hierdie versorger-kindinteraksie-sessies het plaasgevind in 'n stil, goedbeligte vertrek met 'n eenrigtingspieël. Slegs die versorger en die kind was tydens die videoopnamesessies in die vertrek teenwoordig (Coggins \& Carpenter, 1981). Die kind en die versorger is met die maak van die video-opnames so geplaas dat die kind se gesig en liggaam duidelik sigbaar was, sodat oogkontak en intensionele kommunikasiefunksies duidelik waargeneem kon word. 'n Profielbeeld van die versorger is as voldoende beskou om haar gesigsuitdrukkings, liggaamstaal en informele gebare te kon waarneem (Tait, 1993).

Voordat daar met die video-opnames begin is, is riglyne deur Cole en St. Clair-Stokes (1984) toegepas om te verseker dat die monsters van versorger-kindinteraksie verteenwoordigend was van die kind en die versorger se tipiese kommunikatiewe gedrag. Die versorger is byvoorbeeld aangesê om met die kind op dieselfde wyse te speel as waarop hulle by die huis speel.

Die video-opnames was 30 minute lank, waartydens die versorger en die kind met twee ouderdomstoepaslike spelaktiwiteite gespeel het (Tait, 1993; Coggins \& Carpenter, 1981). Sien Tabel 1.

'n Lopende transkripsie van die 30-minutegespreksdata van elke proefpersoon in interaksie met die versorger is gemaak om die herhaalbaarheid van die bevindinge te kon kontroleer (Leedy \& Ormrod, 2001).

\section{Data-optekeningsprosedures}

'n Ongewysigde weergawe van die Communicative Intention Inventory (Coggins \& Carpenter, 1981) is gebruik om die data vervat op die videobande, te kodeer. Die Communicative Intention Inventory het omskrywings ingesluit van die spesifieke kommunikatiewe gedrag wat teenwoordig moes wees om as een van sewe kommunikasiefunksies geklassifiseer te kon word (Tabel 2).

Tabel 2

Definisies van kommunikasiefunksies soos van toepassing op die Communicative Intention Inventory (Coggins \& Carpenter,1981).

\begin{tabular}{|l|l|}
\hline $\begin{array}{l}\text { KOMMUNIKASIEFUNKSIE- } \\
\text { KATEGORIE }\end{array}$ & $\begin{array}{l}\text { Gedrag wat die luisteraar se aandag vestig op 'n voorwerp, die beweging van 'n voorwerp, of op 'n persoon. Kan 'n be- } \\
\text { noeming of 'n beskrywing wees. }\end{array}$ \\
\hline Kommentaar & Gedrag wat 'n ander persoon aanmoedig om 'n taak te verrig. Die kind wag op 'n respons. \\
\hline Versoeke & Die kind druk uit dat die spreker se aksie of voorafgaande uiting hom/haar nie geval nie. \\
\hline Protestering & $\begin{array}{l}\text { Reageer op 'n versoek vir inligting met semanties toepaslike data. Kon slegs gekodeer word as dit op,'-'n vraag gevolg } \\
\text { het. }\end{array}$ \\
\hline Entwoord & $\begin{array}{l}\text { Gedrag wat die luisteraar lei om meer inligting oor 'n voorwerp, 'n aksie, of plek te verskaf. Die luisteraar moes reageer } \\
\text { deur te antwoord. }\end{array}$ \\
\hline Versoeke vir inligting & Die presiese herhaling van die versorger se onmiddellik voorafgaande gebaar of uiting. \\
\hline Nabootsing &
\end{tabular}

Bron: Coggins \& Carpenter (1981)
Die operasionele definisies van die sewe kommunikasiefunksie-kategorieë is op ' $\mathrm{n}$ waarnemingsvorm van die Communicative Intention Inventory uiteengesit. Hierdie waarnemingsvorm is gebruik om die data oor die kommunikasiefunksies van elke proefpersoon, soos vervat op die videobande, op te teken, te klassifiseer en te analiseer.

Elke kommunikasiehandeling van 'n proefpersoon binne die volle video-opname van versorger-kindinteraksie is geïdentifiseer en beoordeel op grond van intensionaliteit. Gedrag is as intensioneel beskou indien die versorger en die kind gesamentlik aan 'n gemeenskaplike aktiwiteit deelgeneem het (Coggins \& Carpenter, 1981).

Die gedrag is afgemerk langs die toepaslike kategorie vir intensionele kommunikasie op die waarnemingsvorm. Slegs die intensionele kommunikasiefunksies wat operasioneel in die Communicative Intention Inventory gedefinieer is, is beoordeel.

\section{Data-analise}

Die data omtrent die aard en die voorkoms van die proefpersone se gebruik van kommunikasiefunksies oor tyd is kwantitatief verwerk deur die voorkomsfrekwensie van die kommunikasiefunksies te bepaal in die vorm van persentasies. Grafieke is van die data opgestel om voorstellings te kon verskaf van die frekwensie van die tipe kommunikatiewe gedrag wat by die proefpersone teenwoordig was en voorstellings te bied van die veranderinge in intensionele kommunikasie oor tyd.

\section{Betroubaarheidskontrole}

Om te verseker dat die dataverwerkingsprosedures herhaal kon word, is die betroubaarheid daarvan gekontroleer deur gebruik te maak van 'n tweede evalueerder tydens data-optekening (Maxwell \& Satake, 1997). 'n Tien-minute-videosnit binne elke video-opname-interval (bv. pre-operatief, 12 maande, 18 maande) is op 'n toevallige basis vir die groep proefpersone gekies. Die drie videosnitte is daarna onafhanklik deur die tweede evalueerder getranskribeer en gekodeer, sodat die interbeoordelaarsbetroubaarheid bepaal kon word. Die interbeoordelaarsbetroubaarheid is bereken deur 'n statistiese formule wat deur Maxwell en Satake (1997) beskryf is.

Die persentasie ooreenstemming wat tussen die navorser en die tweede evalueerder bereik is ten opsigte van die toekenning van intensionele kommunikasie aan 'n spesifieke kommunikasiefunksie kategorie, was $95 \%$. 'n Hoë mate van interbeoordelaars betroubaarheid het dus voorgekom. 


\section{RESULTATE EN BESPREKING}

\section{Kommunikasiefunksies: Pre-operatief}

Figure 1 tot 5 toon aan dat die kommunikasiefunksies, kommentaar op voorwerp of aksie, versoeke vir voorwerp of aksie, protes en bevestiging pre-operatief die meeste deur vier van die vyf proefpersone gebruik is. Die uitsondering is die gebruik van bevestiging, wat nie pre-operatief by proefpersoon 2 wargeneem is nie. Die oorwegende gebruik van kommentaar op voorwerp of aksie en versoeke vir voorwerp of aksie deur al die proefpersone korreleer met die bevindinge deur Wright et al. (2002) dat jong kinders met 'n ernstige gehoorverlies vóór kogleêre inplanting beduidend meer van hierdie twee kommunikasiefunksies gebruik maak as van enige ander kommunikasiefunksie. Rossetti (2001) dui ook aan dat kommentaar en versoeke die twee kommunikasiefunksies is wat die meeste deur jong kinders in die prelinguistiese stadium van taalontwikkeling gebruik word.

Volgens Figure 1 tot 5 het die proefpersone in die huidige navorsing ook dikwels pre-operatief van protes gebruik gemaak om tydens die spelinteraksie intensioneel met die versorger te kommunikeer. Protes ontwikkel vóór die kommunikasiefunksie versoeke vir voorwerp of aksie, en word net soos versoeke deur die jong kind gebruik om sy/haar onmiddellike omgewing te manipuleer (Carpenter, Mastergeorge \& Coggins, 1983). Aangesien jong kinders gewoonlik onmiddellike en konsekwente resultate kry deur voorwerpe of aktiwiteite te weier, mag protes die mees funksionele manier weés waarop kinders in 'n prelinguistiese stádium van taalontwikkeling met hulle versorgers kan kommunikeer (Carpenter et al., 1983). Verder is beide versoeke en protes, kommunikasiefunksies waaraan maklik op 'n nieverbale wyse uitdrukking gegee kan word (Nicholas \& Geers, 1997). Gevolglik word hierdie twee kommunikásiefunksies dikwels deur kinders met 'n ernstige gehoorverlies gebruik, as gevolg van hulle ingekorte verbale kommunikasievaardighede weens die gevolge van die graad van die gehoorverlies op hulle ontwikkeling van verbale taal (Nicholas \& Geers, 1997).

Die resultate in Figure 1 tot 5 toon dat die kommunikasiefunksie bevestiging pre-operatief dikwels deur vier uit die vyf proefpersone gebruik is. Die voorkoms van hierdie kommunikasiefunksie vóór kogleêre inplanting dui aan dat dié vier proefpersone bewus was dat hulle tydens spelinteraksie, ten spyte van hulle ingekorte spraakpersepsie, deur bevestiging respons moes toon op die versorger se voorafgaande uiting

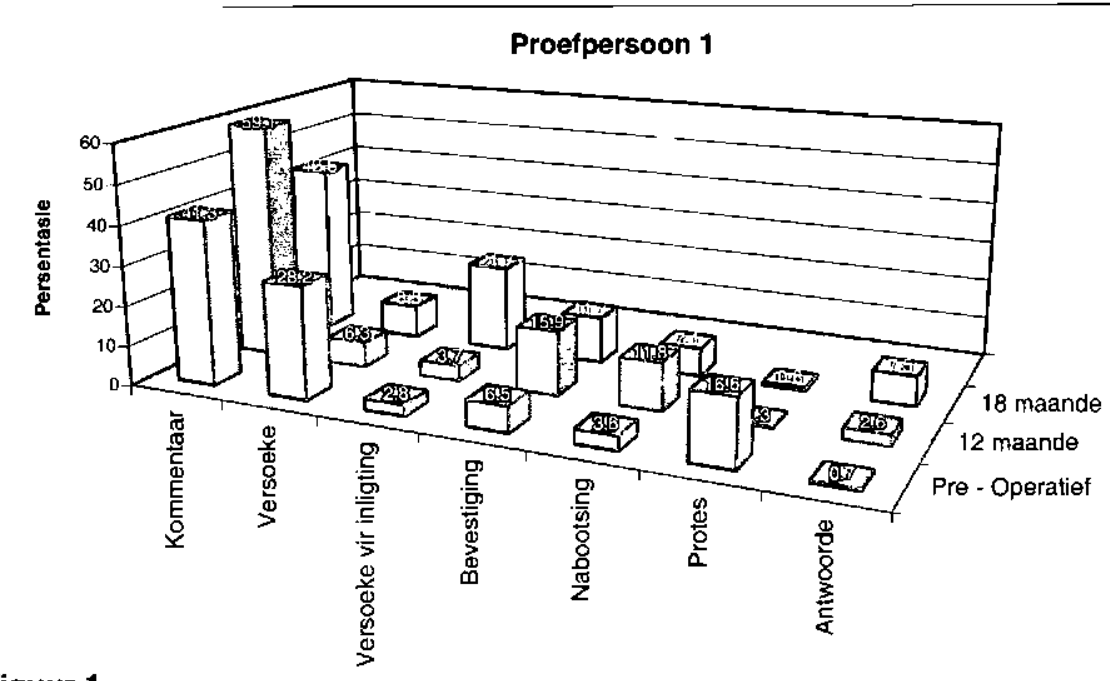

Figuur 1

Die aard en die voorkoms van die kommunikasiefunksies oor tyd by proefpersoon 1.

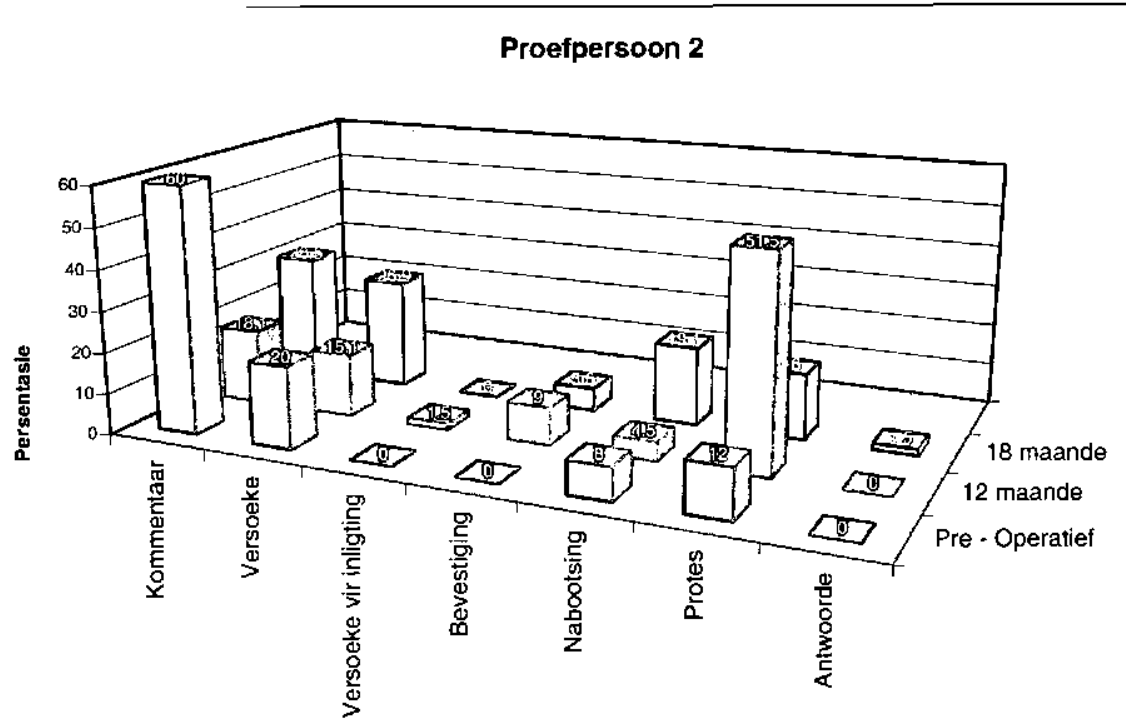

Figuur 2

Die aard en die voorkoms van die kommunikasiefunksies oor tyd by proefpersoon 2 .

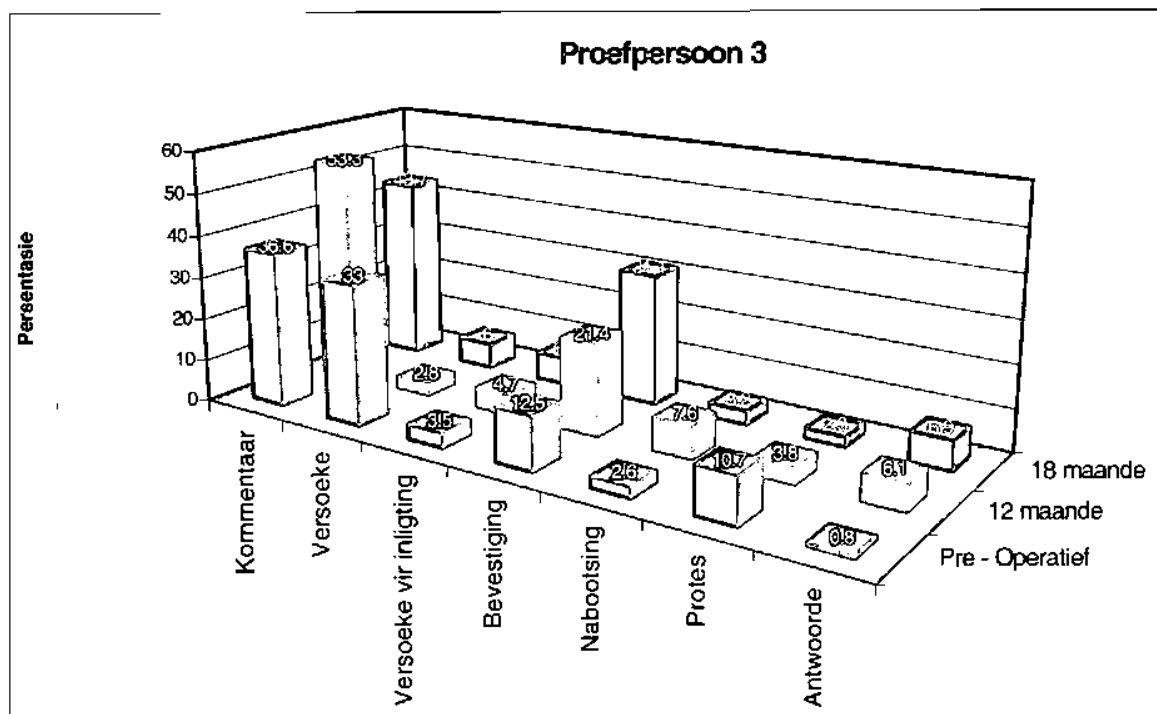

Figuur 3

Die aard en die voorkoms van die kommunikasiefunksies $\infty$ r tyd by proefpersoon 3 . 
(Wetherby \& Prizant, 1989). Hierdie proefpersone het dus meer bevoegdheid geopenbaar om aan gespreksinteraksie deel te neem as proefpersoon 2 wat nie van bevestiging gebruik gemaak het nie (Carpenter et al., 1983).

Die proefpersone se gebruik van bevestiging is verrassend as ' $n$ mens hulle taalontwikkelingsvlak en hulle ingekorte spraakpersepsie in ag neem. Laasgenoemde aspek beïnvloed hulle vermoë om die spreker se voorafgaande uiting ouditief te monitor en toepaslik deur bevestiging daarop te reageer. Die verkreë resultate weerspieël gevolglik die invloed van die proefpersone se kognitiewe ontwikkeling op hulle verwerwing van kommunikasiefunksies soos bevestiging.

Yoshinaga-Itano (1997) het aangedui dat daar 'n gaping bestaan tussen die kognitiewe en linguistiese vaardighede van jong kinders met 'n ernstige gehoorverlies. Die voorkoms van hierdie kognitief-linguistiese gaping gee daartoe aanleiding dat hierdie kinders ten spyte van hulle verbale taalagterstand oor meer gesofistikeerde nieverbale begripstrategieë beskik as wat verwag sal word van kinders met 'n ooreenstemmende vlak van verbale taalontwikkeling (Yoshinaga-Itano, 1997). Daar kan dus tot die gevolgtrekking gekom word dat die kognitiewe ontwikkelingsvlak van vier uit die vyf proefpersone in die huidige navorsing die verwerwing van die kommunikasiefunksie bevestiging positief beïnvloed het.

Volgens Figuur 1 tot 5 het vier uit die vyf proefpersone vóor kogleêre inplanting die vermoë getoon om van nabootsing gebruik te maak om hulle in beurtname te ondersteun. Volgens Figuur 5 het proefpersoon.5 amper ewe veel versoeke vir voorwerpe of aksie gerig as wat sy die versorger se gedrag tydens die spelinteraksie nageboots het. Daarteenoor het proefpersoon 2 (Figuur 2) se kommunikasie-interaksie uit $8 \%$ nabootsing bestaan, terwyl proefpersoon 1 (Figuur 1) en 3 (Figuur 3) minder as 4\% nageboots het en proefpersoon 4 (Figuur 4) glad nie tydens hierdie opname-interval nageboots het nie. Nabootsing speel 'n rol om die kind tydens beurtname te ondersteun wanneer hy/sy nog nie ten volle weet hoe om te reageer nie (Rossetti, 2001). Nabootsing van vokalisasies en gebare is beide belangrike voorlopers tot die ontwikkeling van verbale taal (Rossetti, 2001). In die huidige navorsing het vier uit die vyf proefpersone deur hulle gebruik van nabootsing gedemonstreer dat hulle 'n belangrike voorloper tot verbale taal verwerf het.

Twee kommunikasiefunksies wat ook aanduidings gee van die bevoegdheid

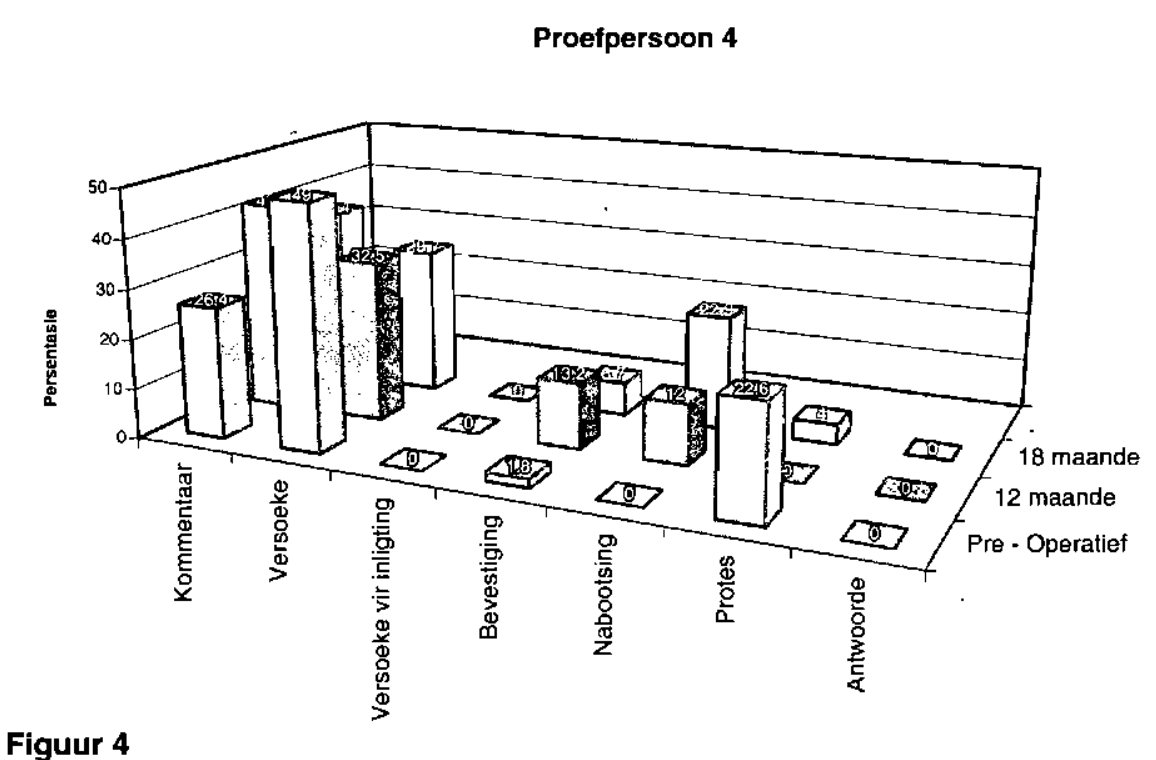

Die aard en die voorkoms van die kommunikasiefunksies oor tyd by proefpersoon 4 . 
inligting en antwoorde, waarskynlik daardeur beïnvloed, ongeag hulle kognitiewe ontwikkeling.

Die aard en die voorkoms van die kommunikasiefunksies wat vóór kogleêre inplanting deur die proefpersone in die huidige navorsing gebruik is, is beinvloed deur hulle kognitiewe ontwikkeling en die effek van die graad van die gehoorverlies op hulle vermoë om vóór kogleêre inplanting binne 'n sosiale konteks verbale taal aan te leer.

Al die proefpersone het vóór kogleêre inplanting tot 'n meerdere of mindere mate kommunikasiefunksies gebruik met die doel om die versorger se gedrag te reguleer (versoeke vir voorwerp of aksie; protes), sosiale interaksie te bewerkstellig (bevestiging) en verwysing met die versorger te deel (kommentaar). Hulle gebruik van hierdie kommunikasiefunksies het hulle onderskeie vermoëns om vóór kogleêre inplanting aan gespreksinteraksie deel te neem, weerspieël.

\section{Kommunikasiefunksies: 12 maande ná kogleêre inplanting}

Volgens Figure 1, 3, 4 en 5 is dit duidelik dat proefpersone 1, 3, 4 en 5, twaalf maande ná kogleêre inplanting meer bewustheid van die versorger getoon het deurdat hulle gepoog het om gereeld gemeenskaplike aandag met die versorger te deel deur kommentaar te lewer op voorwerpe of aksies. Soortgelyke resultate is verkry deur Tait en Lutman (1994). Volgens dié outeurs maak die verbeterde spraakpersepsie dit vir hulle moontlik om sodanige verwysing met die versorger te deel.

Volgens Figure 1, 3, 4 en 5 het daar verder tydens hierdie opname-interval 'n merkbare afname voorgekom in proefpersone $1,3,4$ en 5 se gebruik van die vroegontwikkelende kommunikasiefunksies protes en versoeke vir voorwerp of aksie. Twaalf maande ná kogleêre inplanting het proefpersone $1,3,4$ en 5 dus minder gereeld kommunikasiefunksies gebruik vir gedragsregulering, by. protes en versoeke vir voorwerp of aksie, en meer dikwels gebruik gemaak van 'n kommunikasiefunksie soos kommentaar op voorwerp of aksie wat 'n gespreksfunksie het en bydra tot sosiale interaksie, soos wat dit ook gebruik word deur jonger kinders met normale gehoor (Nicholas, 1994; Wetherby \& Prizant, 1993).

Na aanleiding van die resultate saamgevat in Figuur 2 het proefpersoon 2 daarteenoor steeds hoofsaaklik gebruik gemaak van die kommunikasiefunksies versoeke vir voorwerp of aksie en protes vir gedragsregulering, alhowewel hy begin het om meer verwysing met die versorger te deel deur kommentaarlewering. Proefpersoon 2 se spraakpersepsie ná twaalf maande van kogleêre inplanting, tesame met' sy toenemende vermoë om gemeenskaplike aandag met die versorger te bewerkstellig, het egter waarskynlik daartoe aanleiding gegee dat hy kommunikasiefunksies, soos bevestiging en versoeke vir inligting wat afhanklik is van gespreksdiskoers, tydens hierdie opname-interval begin gebruik het (Coggins \& Carpenter, 1981). Die verbeterde spraakpersepsie wat proefpersoon 2 met 'n kogleêre inplanting ondervind het is weerspieël in ' $n$ verandering in die aard van die kommunikasiefunksies wat hy twaalf maande ná kogleêre inplanting gebruik het.

Met verwysing na Figure 1, 3, 4 en 5 het die voorkomsfrekwensie van die kommunikasiefunksies bevestiging en nabootsing (proefpersone 1, 3 en 4) en versoeke vir inligting en antwoorde (proefpersone 1, 3 en 5) tydens hierdie opnameinterval begin toeneem, alhoewel die voorkomsfrekwensie van versoeke vir inligting en antwoorde steeds laag was by proefpersone 1,3 en 5 . Proefpersone 1,3 en 5 het egter meer gereeld gebruik gemaak van kommunikasiefunksies wat afhanklik is van gespreksdiskoers (Coggins \& Carpenter, 1981). Die toename in die proefpersone se gebruik van hierdie kommunikasiefunksies weerspieël die invloed van verbeterde spraakpersepsie met 'n kogleêre inplanting op die voorkomsfrekwensie van die kommunikasiefunksies en die proefpersone se toenemende vermoë om aan gespreksinteraksie deel te neem (Nicholas \& Geers, 1997).

Volgens Figuur 4 het proefpersoon 4 egter ná twaalf maande van kogleêre inplanting nog nie gebruik gemaak van die kommunikasiefunksies versoeke vir inligting en antwoorde nie. Wright et al. (2002) het ook bevind dat 'n proefpersoon in hulle navorsing twaalf maande ná kogleêre inplanting nog nie versoeke vir inligting gebruik het nie. Die invloed van die afwesigheid van hierdie kommunikasiefunksie op die proefpersoon se latere verbale kommunikasie-ontwikkeling is egter nie deur hulle ondersoek nie. In die huidige navorsing mag proefpersoon 4 se tempo van kommunikasie-ontwikkeling, egter negatief beïnvloed word deur die aard van die kommunikasiefunksies wat hy twaalf maande ná kogleêre inplanting gebruik, wat ooreenstem met die bevindinge wat vir proefpersoon 2 gemaak is (Yoshinaga-Itano, 1997; Yoshinaga-Itano \& Stredler-Brown, 1992).

Ná twaalf maande van kogleêre inplanting het die proefpersone meer gereeld gemeenskaplike verwysing met die versorger gedeel deur kommentaarlewering en 'n verandering in die aard en in die gebruiksfrekwensie van kommunikasiefunksies wat afhanklik is van gespreksdiskoers het by vier uit die vyf proefpersone voorgekom.

\section{Kommunikasiefunksies: 18 maande ná kogleêre inplanting}

Die invloed van die proefpersone se toenemende vermoë om verwysing met die versorger te deel, is ook weerspieël in die aard en die voorkomsfrekwensie van die kommunikasiefunksies wat hulle agtien maande ná kogleêre inplanting gebruik het.

Volgens Figure 1 tot 5 het al die proefpersone tydens hierdie opname-interval steeds minder kommunikasiefunksies vir gedragsregulering gebruik en meer dikwels gebruik gemaak van kommentaarlewering om gemeenskaplike aandag met die versorger te vestig (Wetherby \& Prizant, 1993). Hierdie verhouding tussen kommentaarlewering en die rig van versoeke vir voorwerpe of aksies het vir al die proefpersone gestabiliseer in vergelyking met die vorige opname-interval (sien Figure 1 tot 5). Veral protes, wat gebruik kan word om die gedrag van die versorger te reguleer, het merkbaar afgeneem by al die proefpersone, ook by proefpersoon 2. Die feit dat proefpersoon 2 agtien maande ná kogleêre inplanting minder geprotesteer het tydens kommunikasie-interaksie met sy versorger kan aanduidend wees dat sy kommunikasieseine ná hierdie tydperk tot so 'n mate duideliker en konsekwenter geword het dat die versorger dit makliker kon interpreteer en kommunikasie-interaksie daardeur bevorder kon word (Theadore, Maher \& Prizant, 1990).

Al die proefpersone het ook tydens hierdie opnameinterval die kommunikasiefunksies nabootsing en bevestiging gebruik. Proefpersone 2 en 4 het tydens die kommunikasieinteraksie meer nageboots en minder die versorger se voorafgaande uiting bevestig as tydens die vorige opname-interval. Hierdie intensionele kommunikasiegedrag weerspieël moontlik hierdie proefpersone se toenemende bewustheid van beurtname in gespreksinteraksie en hulle gebruik van spesifiek nabootsing om hulle te help om agtien maande ná kogleêre inplanting kommunikasiegedrag aan te leer wat spesifiek is tot hulle moedertaal (Rossetti, 2001).

Daarteenoor het die voorkomsfrekwensie van nabootsing afgeneem by proefpersoon $3(3.2 \%)$ en $5(6.1 \%)$ en gestabiliseer 
by proefpersoon $1(7.1 \%)$, terwyl die voorkomsfrekwensie van bevestiging by hierdie proefpersone toegeneem het (proefpersoon $3: 31.1 \%$ ) of gestabiliseer het in vergelyking met die vorige opname-interval (proefpersoon 1: $11.7 \%$; proefpersoon 5: $13 \%$ ). Hierdie drie proefpersone het dus agtien maande ná kogleĉre inplanting minder van nabootsing gebruik gemaak om hulle te ondersteun in beurtname, aangesien hulle toenemend bewus geraak het van die wyse waarop hulle op die versorger se voorafgaande uiting moet reageer, bv. deur bevestiging (Rossetti, 2001; Wetherby \& Prizant, 1993). Hulle was dus agtien maande ná kogleêre inplanting meer bevoegd om aan gespreksinteraksie deel te neem as proefpersone 2 en 4 wat op daardie stadium steeds afhanklik was van nabootsing om hulle in beurtname te ondersteun (Carpenter et al., 1983).

Volgens Figure 1 tot 5 het die onderskeie proefpersone ook agtien maande ná kogleêre inplanting merkbaar verskil in hulle gebruik van heuristiese en informatiewe kommunikasiefunksies, soos versoeke vir inligting en antwoorde. Die voorkomsfrekwensie van antwoorde het toegeneem by proefpersone 1, 3 en 5, alhoewel dit agtien maande ná kogleêre inplanting steeds minder as $15 \%$ van die tyd tydens kommunikasie-interaksie gebruik is. Die voorkomsfrekwensie van versoeke vir inligting het by proefpersone 1 en 3 effens afgeneem, maar het begin toeneem by proefpersoon 5. Hierdie kommunikasiefunksie het egter agtien maande ná kogleêre inplanting steeds minder as $15 \%$ van die tyd by al drie hierdie proefpersone voorgekom.

Hierdie resultate korreleer met bevindinge deur Nicholas (1994) dat die kommunikasiefunksies versoeke vir inligting en antwoorde oor tyd toenemend gebruik word deur kinders met 'n ernstige gehoorverlies. 'n Merkbare toename in die gebruik van versoeke vir inligting en antwoorde onderskei kinders met kogleêre inplantings van kinders met 'n ernstige gehoorverlies wat gebruik mak van ander sensoriese hulpmiddels, aangesien eersgenoemde groep se verbeterde spraakpersepsie hulle ontwikkeling van intensionele kommunikasie beïnvloed (Nicholas, 1994).

In die huidige navorsing het proefpersoon 4 egter, volgens Figuur 4, ná agtien maande van kogleêre inplanting steeds geen versoeke vir inligting gerig of antwoorde verskaf tydens kommunikasie-interaksie met die versorger nie. Daarmee saam het proefpersoon 2 nie die vermoë geopenbaar om konsekwent versoeke vir inligting $(0 \%)$ en antwoorde tydens kommunikasieinteraksie te gebruik nie, alhoewel antwoorde $(<4 \%)$ tydens hierdie opname-interval sigbaar was (sien Figuur 2).

Ten spyte van hulle verbeterde spraakpersepsie met 'n kogleêre inplanting het die aard en die voorkoms van die kommunikasiefunksies wat proefpersone 2 en 4 agtien maande ná kogleêre inplanting gebruik het, eerder ooreengekom met die kommunikasiefunksies wat gebruik word deur ernstig gehoorgestremde kinders wat gebruik maak van ander sensoriese hulpmiddels, as met dié van ander kinders met kogleêre inplantings (Nicholas, 1994; Yoshinaga-Itano \& Stredler-Brown, 1992). Hierdie proefpersone het dus verskil van die ander proefpersone in die navorsing ten opsigte van hulle vermoë om die linguistiese inligting te gebruik wat deur die kogleêre inplanting beskikbaar gestel is vir die ontwikkeling van intensionele kommunikasie. Alhoewel proefpersone 2 en 4 oor tyd toenemend bewus geraak het van reëls onderliggend aan beurtname, was hulle vermoë om met die versorger in dialoog te tree ná agtien maande van kogleêre inplanting steeds ingekort. Die aard en die voorkoms van die kommunikasiefunksies wat hulle oor tyd gebruik het, het waarskynlik hulle tempo van kommunikasie-ontwikkeling beïnvloed in vergelyking met die ander drie proefpersone in die navorsing.
Die individuele verskille tussen die proefpersone wat be. tref hulle tempo van intensionele kommunikasie-ontwikkeling is ná agtien maande van kogleêre inplanting weerspieël deur interk. liëntvariasie in die gebruik van heuristiese en informatiewe kom. munikasiefunksies. Tydens hierdie opname-interval het die proefpersone onderling verskil in hulle vermoë om tydens die spelinteraksie met die versorger in dialoog te tree. Die rol wat die aard en die voorkomsfrekwensie van die kommunikasiefunksies speel in die proefpersone se ontwikkeling van gespreksvaardighede ná kogleêre inplanting, het spesifiek tydens die agtien maande opname-interval merkbaar geword.

\section{GEVOLGTREKKINGS}

Die resultate het daarop gedui dat die kinders met 'n ernstige gehoorverlies se ingekorte spraakpersepsie 'n merkbare invloed gehad het op die aard en die voorkomsfrekwensie van die kommunikasiefunksies wat hulle vóór kogleêre inplanting gebruik het. Hierdie gevolgtrekking is gebaseer op die bevinding dat hulle vóór kogleêre inplanting hoofsaaklik gebruik gemaak het van kommunikasiefunksies wat onafhanklik was van gespreksdiskoers, bv. versoeke vir voorwerp of aksie, protes en kommentaar op voorwerp of aksie. Individuele verskille vóór kogleêre inplanting in hulle gebruik van 'n kommunikasiefunksie wat afhanklik was van gespreksdiskoers, naamlik bevestiging, het egter daarop gedui dat hulle kronologiese ouderdom of kognitiewe ontwikkelingsvlak ook 'n rol gespeel het in die aard en die voorkoms van die kommunikasiefunksies wat vóór kogleêre inplanting gebruik is. Beide hulle kognitiewe ontwikkeling en ingekorte spraakpersepsie het dus 'n invloed gehad op hulle gebruik van kommunikasiefunksies vóór kogleêre inplanting, en dit het bygedra tot die voorkoms van individuele verskille in hulle vroeë intensionele kommunikasie-ontwikkeling vóór kogleêre inplanting.

Die aard en die voorkomsfrekwensie van die kommunikasiefunksies wat die kinders met 'n ernstige gehoorverlies ná kogleêre inplanting gebruik het, het daarop gedui dat die ouditiewe stimulering wat deur die kogleêre inplanting verskaf is, hulle gebruik van kommunikasiefunksies positief beïnvloed het Die verbeterde spraakpersepsie wat hulle met 'n kogleêre inplanting verkry het, het bygedra tot die toenemende voorkoms van heuristiese en informaticwe kommunikasiefunksies oor die tydperk van agtien maande van kogleêre inplanting, bv. kommentaar op voorwerp of aksie, bevestiging, versoeke vir inligting en antwoorde. Die aard en die voorkoms van die kommunikasiefunksies het dus merkbaar vóór en ná kogleêre inplanting verskil en het die kinders se toenemende bevoegdheid om aan gespreksinteraksie deel te neem, gedemonstreer.

Hierdie resultate het ook merkbare individuele ${ }^{i}$ verskille tussen die kinders met ' $n$ ernstige gehoorverlies aangetoon ten opsigte van hulle tempo van intensionele kommunikasieontwikkeling en hulle vermoë om agtien maande ná kogleêre inplanting aan gespreksinteraksie deel te neem. Dit het geblyk dat hulle tempo van intensionele kommunikasie-ontwikkeling en gespreksvaardighede ná kogleêre inplanting beïnvloed is deur hulle ontwikkeling van heuristiese en informatiewe kommunikasiefunksies binne die eerste twaalf maande ná kogleêre inplanting. Aangesien heuristiese en informatiewé kommunikasiefunksies afhanklik is van gespreksdiskoers, kan jong ernstig gehoorgestremde kinders se gebruik daarvan 'n aanduiding gee van hulle vermoë om die linguistiese inligting wat deur die kogleêre inplanting beskikbaar gestel word, te verwerk. Interkliëntvariasie in die ontwikkeling van gespreksvaardighede agtien maande ná 
kogleêre inplanting het dus waarskynlik voorgekom as gevolg van onderlinge verskille tussen die kinders wat betref hulle vermoë om die ouditiewe inligting wat deur die kogleêre inplanting verskaf is, vir kommunikasie-ontwikkeling te gebruik.

Die individuele verskille tussen die kinders met 'n ernstige gehoorverlies met betrekking tot die aard en die voorkoms van die kommunikasiefunksies wat hulle vóór en ná kogleêre inplanting gebruik het, het dus daarop gedui dat ouditiewe stimulering alleen nie 'n rol gespeel het in hulle ontwikkeling van intensionele kommunikasie nie, maar dat verskeie ander faktore hulle vordering ná kogleêre inplanting beïnvloed het, bv. hulle kognitiewe ontwikkelingsvlak en hulle ouditiewe prosesseringsvermoë.

Die analise van die kommunikasiefunksies wat jong kinders met 'n ernstige gehoorverlies gebruik bied dus 'n bruikbare wyse waarvolgens hulle gereedheid en potensiaal vir verbale kommunikasie-ontwikkeling vóór kogleêre inplanting bepaal kan word en hulle vordering gedurende die eerste agtien maande ná kogleêre inplanting gemonitor kan word, terwyl hulle oor die algemeen in ' $n$ prelinguistiese stadium van taalontwikkeling is (Tait, 1993).

Die huidige navorsing lewer dus nie net 'n belangrike kliniese bydrae om die kennisbasis uit te brei omtrent faktore wat 'n invloed kan hê op jong kinders met 'n ernstige gehoorverlies se verbale kommunikasie-uitkomste ná kogleêre inplanting nie, maar hou ook implikasies in vir die identifisering van objektiewe en sensitiewe evalueringsprosedures vir die evaluering van hierdie jong kinders se preverbale en vroeë verbale kommunikasievaardighede vóór en ná kogleêre inplanting. Die belang van laasgenoemde aspek word duidelik indien in ag geneem word dat die meerderheid kogleêre-inplantingseenhede tot dusver nie toepaslike evalueringsprosedures geïdentifiseer het ten einde jong ernstig gehoorgestremde kinders, onder die ouderdom van drie jaar, se vroeë kommunikasievaardighede te evalueer nie (McConkey Robbins, 2003). Die stelselmatige evaluering van die vroeë kommunikasievaardighede van jong kinders vóór en ná kogleêre inplanting is nie net onontbeerlik vir die vasstel van intervensiedoelwitte nie, maar dit stel ook objektiewe kliniese bewyse beskikbaar ten opsigte van jong kinders se potensiaal vir verbale kommunikasie-ontwikkeling ná kogleêre inplanting (McConkey Robbins, 2003). Sodanige objektiewe evalueringsresultate dra daartoe by dat professionele persone verbonde aan kogleêre-inplantingseenhede objektiewe besluite kan neem oor baie jong kinders se kandidaatskap vir kogleêre inplanting en toepaslike berading aan hulle gesinne kan verskaf om hulle te ondersteun in die besluitnemingsproses en daarna (Dyar, 2003).

Die huidige navorsing behoort egter gesien te word as slegs die eerste stap tot ' $n$ beter begrip van die invloed van jong kinders se gebruik van kommunikasiefunksies op hulle individuele verbale kommunikasie-uitkomste ná kogleêre inplanting. Hierdie navorsingsprojek wys duidelik op 'n behoefte vir verdere navorsing op hierdie gebied, aangesien die gebruik van 'n enkelgeval-navorsingsontwerp, asook die beperkte aantal proefpersone wat aan hierdie navorsing deelgeneem het, sekere beperkinge op die navorsing geplaas het ten opsigte van die veralgemeenbaarheid van die resultate. Dit blyk ook veral nodig te wees om jonger kinders met kogleêre inplantings (onder die ouderdom van agtien maande) in verdere navorsing van hierdie aard te betrek, aangesien navorsing daarop dui dat die tempo van kommunikasie-ontwikkeling verskil tussen kinders wat kogleêre inplantings ontvang vóór die ouderdom van agtien maande en dié wat kogleêre inplantings ná die ouderdom van twee jaar ontvang (Hammes et al. 2002). Sodanige navorsing word tans veral in die Suid-Afrikaanse konteks benodig in die lig van die feit dat die
Universiteit van Stellenbosch, Tygerberg Akademiese Hospitaal Kogleêre-Inplantingseenheid reeds kogleêre inplantings verskaf het aan drie kinders op die ouderdom van sewe maande (Müller, persoonlike onderhoud, 2 Desember 2004).

Die hoop word gekoester dat verdere navorsing oor die vroeë intensionele kommunikasie-ontwikkeling van baic jong ernstig gehoorgestremde kinders vóór en ná kogleêre inplanting sal bydra om nie net die kliniese hantering van hierdie kinders in die toekoms te verbeter nie, maar ook objektiewe en wetenskaplike resultate beskikbaar sal stel oor jong kinders se kommunikasie-uitkomste volgende op kogleêre inplanting, sodat suksesvol gemotiveer kan word vir staatsbefondsing vir hierdie vlak van dienslewering in Suid-Afrika.

\section{ERKENNING}

Hierdie navorsing is gebaseer op 'n gedeelte van ' $n$ M. Kommunikasiepatologie- verhandeling getitel Intensionele Kommunikasie-Ontwikkeling van Jong Kinders met Kogleêre Inplantings by die Universiteit van Pretoria wat onder leiding van proff. Brenda Louw en René Hugo uitgevoer is.

\section{BRONNELYS}

Carpenter, R.L., Mastergeorge, A.M., \& Coggins, T.E. (1983). The acquisition of communicative intentions in infants eight to fifteen months of age. Language and Speech, 26(2), 101-115.

Coggins, $\mathbb{T} . \mathbb{E} .$, \& Carpenter, $\mathbb{R}$. (1981). The communicative intention inventory: A system for observing and coding children's early intentional communication. Applied Psycholinguistics, 2, 235-251.

Cole, E., \& St.Clair-Stokes, J. (1984). Caregiver-child interactive behaviours: A videotape analysis procedure. The Volta Review, 86, 200-216.

Dyar, D. (2003, April). Assessing deaf children's language and speech skills before and after cochlear implantation. Workshop at Carel du Toit Centre for Hearing Impaired Children, Cape Town, South Africa.

Hammes, D.M., Willis, M., Novak, M.A., Edmondson, D.M., Rotz, L.A., \& Thomas, J.F. (2002). Early identification and cochlear implantation: critical factors for spoken language development. Annals of Otology, Rhinology and Laryngology, 11, 74-78.

Houston, D.M., Ying, E.A., Pisoni, D.B., \& Kirk, K.I. (2003). Development of pre-word-learning skills in infants with cochlear implants. The Volta Review, I03 (4), 303-326.

Kirk, K.I. (2000). Challenges in the clinical investigation of cochlear implant outcomes. In J.F. Niparko, K.I. Kirk, N.K. Mellon, A. McConkey Robbins, D.L. Tucci, \& B.S. Wilson (Eds.), Cochlear implants principles and practices (pp. 225-258). Baltimore: Lippincott Williams \& Wilkins.

Leedy, P.D., \& Ormrod, I.E. (2001). Practical research: planning and design (7th ed.). New Jersey: Prentice-Hall.

Maxwell, $\mathbb{D}$.L., \& Satake, $\mathbb{E}$. (1997). Research and statistical methods in communication disorders. Baltimore: Williams \& Wilkins. 
McConkey Robbins, A. (2003). Communication intervention for infants and toddlers with cochlear implants. Topics in Language Disorders, 23(1), 16-33.

McConkey Robbins, A., Green, J., \& Bollard, P. (2000). Language development in children following one year of Clarion implant use. Annals of Otology, Rhinology and Laryngology, 109(12), 94-95.

Nicholas, J.G. (1994). Sensory aid use and the development of communicative function. The Volta Review, 96(5), 181-198.

Nicholas, J.G., \& Geers, A.E. (1997). Communication of oral deaf and normally hearing children at 36 months of age. Journal of Speech, Language and Hearing Research, 40(6), 1314-1327.

Osberger, M.J. (1995). Speech perception and production skills in children with cochlear implants. In G. Plant, \& K.E. Spens (Eds.). Profound deafness and speech communication (pp. 231-261). London: Whurr Publishers.

Osberger, M.T., Todd, S.L., Berry, S.W., Robbins, A.M., \& Miyamoto, R.T. (1991). Effect of age at onset of deafness on children's speech perception abilities with a cochlear implant. Annals of Otology, Rhinology and Laryngology, 100, 883-888.

Penn, C. (1993). Sign language in South Africa. International symposium: Care for multiple disabled deaf people. Worcester, South Africa: Institute for the Deaf.

Pisoni, D.B. (2000). Cognitive factors and cochlear implants: Some thoughts on perception, learning, and memory in speech perception. Ear and Hearing, 21, 70-78.

Pisoni, D.B., Cleary, M., Geers, A.E., \& Tobey, E.A. (2000). Individual differences in effectiveness of cochlear implants in prelingually deaf children: Some new process measures of performance. The Volta Review, 101, 111-164.

Robbins, A.M., Renshaw, J., \& Berry, S. (1991). Evaluating meaningful auditory integration in profoundly hearing impaired children. American Journal of Otology, I2, 144-150.

Rossetti, L.M. (2001). Communication intervention: Birth to three ( $2^{\text {nd }}$ ed.). London: Singular Publishing Group.

Sanderson, G., \& Nash, L.S. (2002). Outcomes beyond technology. Sydney, Australia: Cochlear Limited.
Tait, M. (1993). Video analysis: A method of assessing changes in preverbal and early linguistic communication following cochlear implantation. The first European symposium on paediatric cochlear implantation, Nottingham, Great Britian.

Tait, M., \& Lutman, M.E. (1994). Comparison of early communicative behaviour in young children with cochlear implants and with hearing aids. Ear and Hearing, 15(5), 352-361.

Tait, M., Lutman, M.E., \& Robinson, K. (2000). Preimplant measures of preverbal communicative behavior as predictors of cochlear implant outcomes in children. Ear and Hearing, 2I(1), 18-24.

Theadore, G., Maher, S.R., \& Prizant, B.M. (1990). Early assessment and intervention with emotional and behavioral disorders and communication disorders. Topics in Language Disorders, 10(4), 42-56.

Tyler, R.S. (1993). Speech perception by children. In R.S. Tyler (Ed.), Cochlear implants: Audiological foundations (pp. 191-256). San Diego, CA: Singular Publishing Group.

Wetherby, A.M., \& Prizant, B.M. (1989). The expression of communicative intent: Assessment guidelines. Seminars in Speech and Language, 10(1), 77-88.

Wetherby, A.M., \& Prizant, B.M. (1993). Profiling communication and symbolic abilities in young children. Journal of Childhood Communication Disorders, 15(1), 23-32.

Wetherby, A.M., \& Rodriguez, G.P. (1992). Measurement of communicative intentions in normally developing children during structured and unstructured contexts. Journal of Speech and Hearing Research, 35, 130-138.

Wright, M., Purcell, A., \& Reed, V.A. (2002). Cochlear implants and infants: Expectations and outcomes. Annals of Otology, Rhinology and Laryngology, 111, 131-137.

Yoshinaga-Itano, C. (1997). The challenges of assessing language in children with hearing loss. Language, Speech, and Hearing Services in Schools, 28, 362-373.

Yoshinaga-Itano, C., \& Stredler-Brown, A. (1992). Learning to communicate: Babies with hearing-impairments make their needs known. The Volta Review, 95, 107-129.

Zwolan, T.A. (2000). Selection criteria and evaluation. In S.B. Waltzman, \& N.L. Cohen (Eds.), Cochlear implants (pp. 63-71). New York: Thieme Medical. 